\title{
Macroalgal Blooms on the Rise along the Coast of China
}

\author{
Jianheng Zhang, Yuanzi Huo and Peimin He* \\ Shanghai Ocean University, China
}

Submission: August 01, 2017; Published: September 27, 2017

*Corresponding author: Peimin He, PhD, Shanghai Ocean University, College of Marine Ecology and Environment, 201306, China,

Email:pmhe@shou.edu.cn

\begin{abstract}
A broad spectrum of events that come under the category of macroalgal blooms are recognized world-wide as a response to elevated levels of eutrophication in coastal areas. In the Yellow Sea of China, green tides have consecutively occurred 10 years, which is considered as the world's largest Ulva blooms. However, in recently years, golden tides caused by Sargassum seaweed have also been on the rapid rise, resulting in dramatic damage to the environment and economy again. This review introduced the formation of two macroalgal blooms in the Yellow Sea and reasonable measures to mitigate them, thus safeguarding the intrinsic and commercial value of coastal marine ecosystems.
\end{abstract}

\section{Introduction}

Nutrient inputs to coastal waters have increased in coastal environments worldwide as a direct consequence of the growing human population and increased settlement and use of coastal areas [1]. These changes in nutrient availability lead to increased eutrophication, a growing threat facing coastal ecosystems [2]. One common symptom of eutrophication is profuse blooms of marine macroalgae [3-5], which are formed by the excessive growth of some macroalgae species living in the intertidal zone, now macroalgal blooms are widespread along the coasts of the world $[4,6,7]$.

Macroalgal blooms had negative effects on marine intertidal ecosystems, including changing ecosystem structure and decreasing biodiversity [8]. Meanwhile, due to the competition for light and space, seaweed tides could lead to declining populations or reduced reestablishment capability of seagrass beds [9]. Besides, when the algae died and sunk to the bottom, the consumption of dissolved oxygen may cause a local "dead zone" with hypoxic conditions, resulting in a shift from a highdiversity mixture to low-diversity assemblages of fast-growing annuals, and invertebrate, fish, and even marine mammal kills [10].

With the rapid growth of economy in recent years, eutrophication has been dramatically increasing along the coast of China. For that reason, Yellow Sea of China experienced world's largest green tide and golden tide (Figure 1). In this review, we will introduce new idea and update current understanding of the two macroalgal blooms.

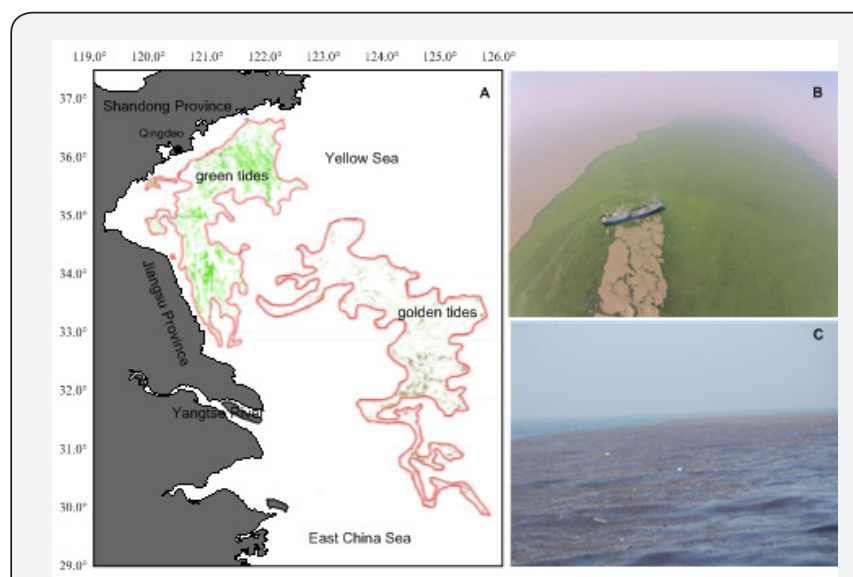

Figure 1: Satellite images for green tides and golden tides in the Yellow Sea and East China Sea $(A)$ and the photos for the floating green tides and golden tides in the field ( $B$ and $C$ ).

\section{Green Tides}

In 2007, the green tides firstly appeared in the coast of Yellow Sea with the covered area of only $21 \mathrm{~km}^{2}$. However, in late June 2008, a $600 \mathrm{~km}^{2}$ green-tide occurred along the coast of Qingdao, where the $29^{\text {th }}$ Olympic Sailing Game events were soon started. This green tides persisted for more than 2 weeks, during which over 10,000 people were organized to remove more than 
one million tons of algae from the Qingdao coastline. Totally, an exceeding US\$100 million was cost to maintain an algae-free area of water near Qingdao for the Olympic sailing competition [11]. Until now, the green tides have occurred for consecutive 10 years and become an annual summer event in the Yellow Sea, resulting in serious damage to the ecological environment and ecosystem service functions.

Although the initial search for the cause of the 2008 macroalgal bloom in Qingdao focused on local coastal eutrophication and the action of tides and wind in bringing the algae ashore, a series of satellite images clearly demonstrated that the formation of the massive green tide in 2008 was a broad regional process across the Yellow Sea. Field observation and physical oceanographic modeling indicated that the green tides were repeatedly original from Subei shoal of Southern Yellow Sea (Figure 2A), which are unique in terms of their huge geometric scale, abundant sediment supply associated with large rivers, siltdominated sediments and an offshore radial sand ridge and was and is an ideal place for Pyropia aquaculture. When harvesting of Pyropia and cleaning of ropes, rafts and other attachments, the fouling attached Ulva seaweeds were scraped and threw away by fishermen (Figure 2B \& 2C). The detached Ulva with structure of air sacs will float, keep growing and drift $200 \mathrm{~km}$ northwards to the Northern Yellow Sea under the driven of currents and surface winds. The small patches of floating green algae drifted for about one and a half months, and eventually developed into the world's largest green tide ever reported, reaching a maximum algal mat cover of $3489 \mathrm{~km}^{2}$, scattered across an area of coastal sea of about $84,109 \mathrm{~km}^{2}$, and producing extraordinary amounts of algal biomass [12]. Eventually, most of these algae landed along the coast of Qingdao city and resulted in a significant impact on the local environment and economy.

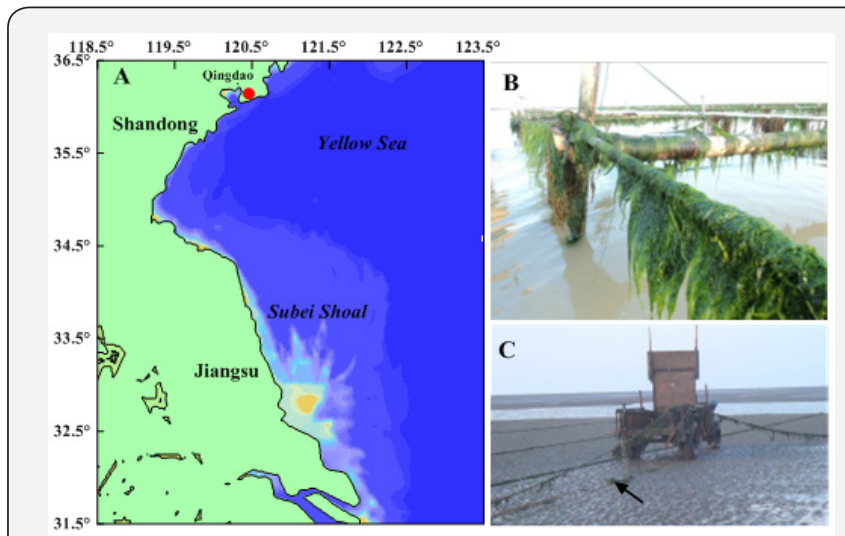

Figure 2: Maps of Subei shoal (A), attached Ulva seaweed on the Pyropia aquaculture raft located in Subei Shoal (B) and the detached Ulva seaweed scraped from Pyropia aquaculture raft by fishermen $(\mathrm{C})$.

\section{Golden Tides}

Also in the Yellow Sea of China, another macroalgal blooms as golden tides which caused by Sargassum seaweed is rising rapidly. The Sargassum thallus is leathery, tough and differentiated into features that resemble leaves and a stem, and has well-developed gas bladders for flotation, even an individual seaweed can reach up to $4 \mathrm{~m}$ long (Figure $3 \mathrm{~A}$ ). In previous years, golden tides occurred without drawing attention due to drifting to deep sea and no damage to coast area. However in 2017, the under the driven of uncommon currents and winds, floating Sargassum thallus surprisingly attacked the coast of Yellow Sea, resulting in dramatic damage to Pyropia aquaculture, almost only a half of Pyropia production was kept (Figure 3B). Through the combination of morphological, molecular and satellite remote sensing analysis, the source of the Sargassum blooms was located in the coast of East China Sea, indicating that blooms is a sea-cross disaster that originates in East China Sea and blooms in the Yellow Sea.

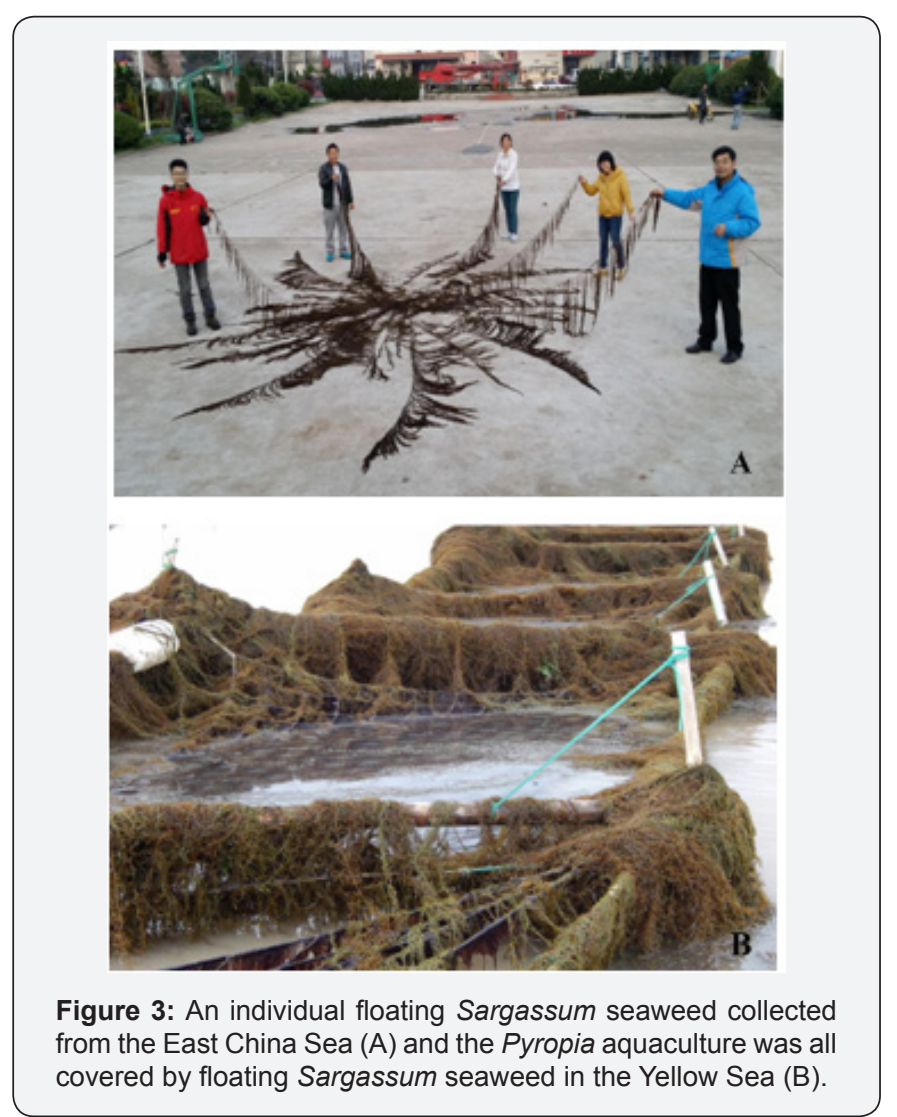

\section{Prevention, Control, and Mitigation}

The cause of macroalgal blooms have generally been attributed to poor water quality, e.g., eutrophication from agricultural runoff or urban-derived pollution, which can lead to overgrowth of macroalgae. The eutrophication is a global problem which could not be solved in a short time through reducing the external load of nutrients or directly manipulating the water body ecosystem. So many papers have reported that the targeting macroalgae, Ulva and Sargassum are edible and characterized by high nutritional value. It has been shown, that they are rich in lipids, proteins and carbohydrates. Special attention should be also paid to the considerable content of omega polyunsaturated 
fatty acids, which are regarded as beneficial to human health [13]. Through collecting floating macroalgae, on the one hand, the total biomass can be reduced greatly, on the other hand, the fouling macroalgae could be process into high value products such as food, fertilizer, animal feed and so on. Thus harvesting the macroalgae, a valuable raw material, before they beach could well be developed into an effective solution.

\section{Acknowledgement}

Special thanks to all researchers and graduated students who conducted the work on this project. This study was sponsored by National Natural Science Foundation of China (Grant No. 41576163), Shanghai Sailing Program (17YF1407900), and the Ocean Public Welfare Scientific Research Project, China (201205010).

\section{References}

1. Valiela I (2006) Global Coastal Change. Blackwell Publishing, Massachusetts, USA.

2. Bricker SB, Longstaff B, Dennison W, Jones A, Boicourt K, et al. (2008) Effects of nutrient enrichment in the nation's estuaries: a decade of change. Harmful Algae 8: 21-32.

3. Lavery PS, Lukatelich RJ, McComb AJ (1991) Changes in the biomass and species composition of macroalgae in a eutrophic estuary. Estuarine, Coastal and Shelf Science 33: 1-22.

4. Morand P, Merceron M (2005) Macroalgal population and sustainability. Journal of Coastal Research 21(5): 1009-1020.

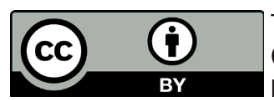

This work is licensed under Creative Commons Attribution 4.0 Licens

DOI: 10.19080/OFOAJ.2017.04.555646
5. Fox SE, Stieve E, Valiela I, Hauxwell J, McClelland J (2008) Macrophyte abundance in Waquoit Bay: effects of land-derived nitrogen loadson seasonal and multi-year biomass patterns. Estuaries and Coasts 31(3): 532-541.

6. Raffaelli DG, Raven JA, Poole LJ (1998) Ecological impact of green macroalgal blooms. Oceanography and Marine Biology: An Annual Review 36: 97-125.

7. Ye NH, Zhang XW, Mao YZ, Liang CW, Xu D, et al. (2011) 'Green tides' are overwhelming the coastline of our blue planet: taking the world's largest example. Ecological Research 26: 477-485.

8. Franz DR, Friedman I (2002) Effects of a macroalgal mat (Ulva lactuca) on estuarine sand flat copepods: an experimental study. Journal of Experimental Marine Biology and Ecology 271: 209-226.

9. Raberg S, Berger-JR, Bjorn A, Graneli E, Kautsky L (2005) Effects of Pilayella littoralison Fucus vesiculosus recruitment: implications for community composition. Marine Ecology Progress Series 289: 131139.

10. Hallegraeff GM (1993) A review of harmful algal blooms and their apparent global increase. Phycologia 32(2): 79-99.

11. Wang XH, Li L, Bao X, Zhao LD (2009) Economic cost of an algae bloom cleanup in China's 2008 Olympic sailing venue. Eos Trans AGU 90(28): 238-239.

12. Liu DY, Keesing JK, He PM, Wang ZL, Shi YJ, et al. (2013) The world's largest macroalgal bloom in the Yellow Sea, China: Formation and implications. Estuarine, Coastal and Shelf Science 129: 2-10.

13. Mamatha BS, Namitha KK, Senthil A, Smitha J, Ravishankar GA (2007) Studies on use of Enteromorpha in snack food. Food Chemistry 101: $1707-1713$

\section{Your next submission with Juniper Publishers will reach you the below assets}

- Quality Editorial service

- Swift Peer Review

- Reprints availability

- E-prints Service

- Manuscript Podcast for convenient understanding

- Global attainment for your research

- Manuscript accessibility in different formats ( Pdf, E-pub, Full Text, Audio)

- Unceasing customer service

Track the below URL for one-step submission https://juniperpublishers.com/online-submission.php 